\title{
OIL VOLATILITY PASS THROUGH AND REAL EXCHANGE MISALIGNMENT IN LEADING COMMODITY EXPORTING COUNTRIES
}

Past research has shown how real Exchange rates follow a univariate nonlinear process that approximates their behavior in terms of transaction costs. However, little or nothing has been said about alternative sources of nonlinearity in commodity exporting countries. Our paper investigates the missing link between the Real Exchange Rate Commodity Prices equilibrium by employing an oil price volatility measure as an external source of short-term fluctuations. Our estimates show that the Real Exchange Rate Commodity price relationship appears to be nonlinear with respect to oil price variation, and that the goodness of fit of the nonlinear specifications appears to outperform that of the equivalent linear models. The equilibrium speed of adjustment appears to be different in the two branches of the relationship: in the majority of the threshold models, the negative volatility regime presents a faster speed of adjustment and in some cases a most significant one.

Keywords: Transition regression model; real exchange rate; nonlinearities; oil prices; commodity prices

" N. Rubino, Ph.D., University of Barcelona, Faculty of Economics and Business (e-mail: Nicola.rubino@ub.edu).The paper was received on 07.11.2018. It was accepted for publication on 19.02.2020 


\section{Introduction}

In the 2000s, studies on the relationship between commodity prices and real exchange rates have found considerable, although country-case limited, evidence of a long run relationship between such variables. Among the most relevant examples, we find Chen and Rogoff (2003) and Cashin, Cespedes, and Sahay (2004), who first examined and confirmed the existence of a stable relationship between REER and commodity prices, the former researchers in Australia, Canada and New Zealand, the latter in one third of a large group of commodity exporting countries. More recently, Bodart, Candelon, and Carpentier (2012) analyzed through non-stationary panel data techniques a monthly panel of sixty-eight countries and found evidence of a threshold export weight of $20 \%$, necessary for the long run relationship to hold, while Bodart, Candelon, and Carpantier (2015) examined the extent to which structural factors such as trade or financial openness and exchange rate regimes influence the strength of the relationship between real exchange rates and commodity prices. In the very recent past, much attention has been put in the idea that fluctuations in commodity prices might drive away economic aggregates from their equilibrium value. Some very recent examples, aimed at explaining the relationship between growth and commodity prices volatility, include the recent works of Cavalcanti, Mohaddes, and Raissi (2011) on macroeconomic growth implications of oil price volatility in the resource curse and Cavalcanti, Mohaddes, and Raissi (2014) on the effect of volatility of a commodities term of trade variable on growth, as well as the out of sample forecasting qualities of oil price nonlinearities in the determination of the real exchange rates of oil producing countries (Ferraro, Rogoff, and Rossi (2015)) or on output growth (as in Hamilton (2003). See Kilian and Vigfusson (2011) for an exhausting overview).

In this paper, we exploit part of the selection methodology as in Cashin, Cespedes, and Sahay (2004) and Bodart, Candelon, and Carpantier (2015) to select a group of commodity countries, analyzing the relationship between leading commodity prices ${ }^{1}$ and real effective exchange rates, according to the behavioral framework introduced by MacDonald (1998). We focus on non-linearity in three aspects. First, we test for unit roots using four test statistics that account for the presence of structural breaks, two based on Perron and Vogelsang (1992), Perron (1997) and Perron and Vogelsang (1998), which do not consider the possibility of a structural break in the alternative stationary/trend stationary hypothesis, and two devised by

${ }^{1}$ The idea of using a single commodity price to represent a terms of trade is not new. Cuddington and Urzua (1989) for instance tested the Prebisch-Singer hypothesis in a time series context using primary product prices. However, since the seminal paper of Deaton and Miller (1996), studies on the relationship between REER and commodity prices have mainly focused on the construction of more complex weighted indices of commodity prices. 
Lee and Strazicich (2003) and Lee and Strazicich (2013), for one or two deterministic breaks, which unambiguously imply trend stationarity as a result of the rejection of the null hypothesis. We thus proceed to test for a possible co-integrating relationship through the Gregory and Hansen (1996a) $C=T$ test, complemented by the Carrion-i Silvestre and Sanso (2006) model $A$ test. Second, in those countries where a long run relationship was found, we estimate the co-integrating vector through the dynamic ordinary least squares approach (DOLS) proposed by Stock and Watson (1993) including the estimated break and calculate an almost behavioral REER misalignment. Third, we fit the measure into a transition regression model with an exogenous threshold ${ }^{2}$ to evaluate the impact of oil price variations on other commodities and thus on the relationship between REER and leading commodity prices. The reason why we use leading commodity prices instead of a more complex commodity terms of trade variable is also threefold: on one side, this would prevent weighting. Weighted prices indexes do not only reject changes in relative prices but are also affected by the substantial variation in time of relative export weights. As a second drawback, the relationship between the REER and the index would depend on how the prices chosen for indexation are correlated across time. If all prices were perfectly negatively correlated, the relationship between the REER and the index would be lost, or at least subject to a downward bias. ${ }^{3}$ As a third remark, since one of our objectives is estimating how oil price variations influence the relationship between REER and other commodity prices, the adoptions of single commodities allows for a more clearer identification of their relationship with oil price fluctuations.

The rest of the paper is thus organized as follows: in Section 1.1, we present a brief literature review related to our analysis. In Section 1.2, we present the methodology and the data of the paper. In Section 2, we perform a series of unit root test, residual co-integration analysis, and estimate REER elasticities to commodity prices. In Section 3, we estimate a threshold regression model with an exogenous oil price variability threshold for the countries where a co-integrating relationship between REER and commodity prices was found. Finally, Section 4 concludes the paper with some suggestions for further developments.

\subsection{Literature review}

There are no practical examples of the direct influences of oil prices in the determination of the real Exchange rate of commodity exporting countries. How-

\footnotetext{
${ }^{2}$ As we fit a variable in first differences as an exogenous threshold, this kind of model is also known as momentum model.

3 Bodart, Candelon, and Carpentier (2012).
} 
ever, being the Oil price an ideal component of the extended production function in many commodity exporting countries, its direct effect could lead to nonlinear but symmetrical changes in the equilibrium relationship between Exchange rates and commodities. Past research (Michael, Nobay, and Peel (1997), Obstfeld and Taylor (1997), Taylor, Peel, and Sarno (2001), (Imbs, Ravn, Mumtaz, and Rey (2003)) has shown how real Exchange rate follows a univariate nonlinear process that approximate its behavior in terms of menu costs. However, little or nothing has been said about alternative sources of nonlinearity in commodity exporting countries. ${ }^{4}$ There is no doubt that a long run equilibrium relationship between commodity prices and oil exists in the long run. Puzzlingly, literature linked to the behavioral definition of exchange rates has never considered making a determinant out of it (on the definition of behavioral equilibrium of the Exchange Rate, see MacDonald (1998)). There is currently some evidence of the pass-through of oil price changes to other commodities (Baffes (2007), Chaudhuri (2001)), which tends in general to be significant regardless of the type of commodity due to both demand and supply side mechanisms. ${ }^{5}$ To our knowledge, no research has yet attempted to explore the nexus which relates oil price volatility pass-through over commodity prices as a mechanism of regime determination of the relationship between real exchange rates and commodity prices, while literature related to the nonlinear relationship between Oil prices and Output is, to say the least, very large (see Kilian and Vigfusson (2011) for a full overview of it). Using single commodity price variables, we investigate more clearly those REER-commodity couples which would more prominently be affected by the existence of an exogenous oil price variation regime. Targeting as objective variable the REER, Michael, Nobay and Peel (1997) make the point that small deviations from an implied Purchasing Power Parity equilibrium will not be corrected by a process of commodity arbitrage given the existence of transaction costs, while higher deviations are expected to be corrected without incurring in opportunity cost issues. In that model, this implies that small/medium size deviations are eliminated more slowly than large deviations, and non-homogeneous agents grant a smooth transition between the two regimes and across time. However, being past analyses targeted at exploiting and testing the long run PPP theory, nonlinear modelling would always follow a univariate process and reversion to the unconditional mean of the REER subject to Rogoff (1996) exchange rate mean reversion puzzle. In this paper, in the spirit of model specifications involving proxies capturing additional nonlinearities as the net oil price increase proposed in Hamilton (1996) and Hamilton (2003) or the more naive Mork (1989) oil price variation mea-

${ }^{4}$ Among the few attempts, see the recent Coudert, Couharde, and Mignon (2015) work on the impact of volatility in commodity and financial markets on the REER-commodity prices relationship.

${ }^{5}$ See Baffes (2007) for an analysis of such mechanisms. As a useful reminder, the author finds out that the pass-through elasticities of crude oil price changes to agriculture tends to be close to 0.17 , while the pass-through on metals to 0.11 . 
sure, we use oil price variation as simple measure to capture arbitrage opportunities given by increasing/decreasing transaction costs. All else equal, in periods of negative oil volatility, we would expect the speed of convergence of the REER to be higher when compared to periods of positive oil volatility.

\subsection{Methodology and Data}

We consider a group of twenty-five commodity exporters. In search of a sufficiently long sample period in monthly frequencies ${ }^{6}$, our REER and commodity prices series were sourced from the International Monetary Fund (IMF) International Financial Statistics database. The nominal prices we employ were coupled to their respective REER following Bodart, Candelon, and Carpantier (2015) selection. ${ }^{7}$ The series were indexed with respect to January 1995 and deflated by a manufacture unit value index $(M U V)^{8}$ calculated for a group of twenty advanced countries, in order to construct series of real commodity prices. All the variables are expressed in logarithms. The countries we consider were selected conditional on the availability of data from the sources we mentioned above and the export weight of their leading exported commodity. The whole set of countries is reported in Tables 1 and 2.

After unit root and co-integration testing, the co-integrating vector was estimated as:

$$
\begin{gathered}
\text { REER }_{t}=\alpha_{1}+\beta C O M M_{t}+\alpha_{2} t+\alpha_{3} D U_{t}+\varepsilon_{t} \\
\text { where } D U_{t}=1 \text { if } t>T_{b}, 0 \text { otherwise }
\end{gathered}
$$

where $R E E R_{t}$ represents the real effective exchange rate; $C O M M_{t}$ is the leading commodity price variable; $t$ is a deterministic time trend; $D U_{t}$ is a binary break level dummy, and $T b$ represents the time of a deterministic change in the level of the relationship, which we retrieved endogenously from the co-integration analysis.

${ }^{6}$ Quarterly series were available. To verify possible implications of a lower frequency for the unit root tests, we run the Perron and Vogelsang (1992) test in quarterly frequencies for the REER. Results were pretty much the same as in monthly frequency.

${ }^{7}$ Our selection basically entailed checking for all the available series from the IMF which were employed by Bodart, Candelon, and Carpantier (2015), conditional on the availability of data and excluding those countries whose main commodity export was crude petroleum.

${ }^{8}$ This deflator, among others, is also available freely in the IMF's International Financial Statistics database. 
Table 1

\section{COUNTRIES AND LEADING COMMODITY COUPLES}

\begin{tabular}{|l|l|c|}
\hline \multicolumn{1}{|c|}{ COMM $_{\mathbf{t}}$} & REER $_{\mathbf{t}}$ & Weight \\
\hline Cotton & Benin & 61 \\
\hline & Mali & 33,48 \\
\hline & Pakistan & 20,52 \\
\hline Tobacco & Malawi & 60,5 \\
\hline & Zimbabwe & 19,53 \\
\hline Copper & Zambia & 59,99 \\
\hline & Chile & 30,79 \\
\hline Gold & Mali & 54,05 \\
\hline & Burundi & 35,45 \\
\hline Coffee & Ghana & 28,56 \\
\hline & Burundi & 50,98 \\
\hline & Ethiopia & 46,43 \\
\hline & Uganda & 36,87 \\
\hline
\end{tabular}

Country and commodity couples according to Bodart, Candelon and Carpantier (2015). Countries where oil was considered a leading exported commodity and which were not available at the IMF although being present in Cashin, Cespedes and Sahay (2004) were discarded from the analysis.

Table 2

\section{COUNTRIES AND LEADING COMMODITY COUPLES}

\begin{tabular}{|l|l|c|}
\hline \multicolumn{1}{|c|}{ COMM $_{\mathbf{t}}$} & \multicolumn{1}{c|}{ REER $_{\mathbf{t}}$} & Weight \\
\hline Uranium & Niger & 41,73 \\
\hline & Benin & 29,9 \\
\hline Cocoa & Ivory Coast & 34,1 \\
\hline & Ghana & 33,16 \\
\hline Aluminium & Mozambique & 33,44 \\
\hline Soya & Paraguay & 32,72 \\
\hline Fish & Mauritania & 30,96 \\
\hline & Mozambique & 19,87 \\
\hline Bananas & Dominica & 29,2 \\
\hline & Ecuador & 17,83 \\
\hline Tea & Kenya & 21,2 \\
\hline Crustaceans & Mozambique & 18,96 \\
\hline
\end{tabular}

Country and commodity couples according to Bodart, Candelon and Carpantier (2015). Countries where oil was considered a leading exported commodity and which were not available at the IMF although being present in Cashin, Cespedes and Sahay (2004) were discarded from the analysis. 
The residual based unit root tests we employed in the analysis are four additive-outlier type tests, where we allowed for one and two structural breaks in the levels of the variables and in its first differences, while estimating the cointegrating relationship only for a single break to account for the issue of data mining. ${ }^{9}$ To account for the ambiguity issues underlined by Lee and Strazicich (2001), we employ and evaluate the results of their one and two break Endogenous Lagrange Multiplier unit root tests. As a strategy for unit root testing, we followed the approach suggested by Dickey and Pantula (1987), starting from first differences and then analyzing levels of the variables, drawing our conclusion on the order of integration of the series based on the non-rejection of the null hypothesis. After checking for the order of integration of the variables, from which we draw information upon which pair of countries-commodities could be specified as the relationship in Equation (1), we employ the $C=T$ specification from Gregory and Hansen (1996a) to check for the existence of a long run equilibrium among the variables and estimate endogenously a break date. Furthermore, we complemented the co-integration analysis with model $A$ from Carrion-i-Silvestre and Sanso (2006), which allows to test the null hypothesis of co-integration with a structural break against the alternative of no co-integration..$^{10}$ We briefly present the results for the order of integration analysis, the co-integration tests and the DOLS estimates of the cointegrating vectors in Section 2.

Once the estimated coefficients from the DOLS estimations were obtained, we calculated the currency misalignment as the gap between the observed exchange rate and the behavioral one as:

$$
M E E R_{t}=R E E R_{t}-\left(\theta \hat{\alpha}_{1}-\hat{\beta} C O M M_{t}+\hat{\alpha}_{2} t+\hat{\alpha}_{3} D U_{t}\right)
$$

Where $M E E R_{t}$ represents the obtained misalignment series, and the hatted coefficients the estimates from the DOLS estimation technique. ${ }^{11}$ As the structural

${ }^{9}$ The Perron and Vogelsang (1992) test was originally specified as a test with a level shift only and no trend in the testing equation, while in the Perron and Vogelsang (1998) the test is also allowed to have a trend. For the sake of a qualified analysis of the REER, and following Papell and Prodan (2006) discussion over different interpretations of the Purchasing Power Parity theory, we consider only a break in the levels.

${ }^{10}$ The specification we choose, model $A$, would account for a break in the level of the cointegrating relationship and $\mathrm{t}$ a trend. This appears to be the most natural alternative to the Gregory and Hansen (1996a) $C=T$ test. For a review of the relative performance of co-integration tests based on the null of co-integration, see Ludwig (2013).

${ }^{11}$ A similar measure of deviation from a long run equilibrium is present in Baum, Barkoulas, and Caglayan (2001), were the authors estimated exponential smooth transition autoregressive models of deviations from purchasing power parity that were obtained using the Johansen co-integration methodology for a group of seventeen advanced countries. 
variation was embedded into the misalignment, the last step required only fitting the lagged value of the misalignment in a symmetrical transition model and evaluate the impact of regime switching in oil price volatility on the relationship between REER and commodity prices. The model we selected is a simple transition model, where the chosen threshold variable, price volatility, is the first difference of the international oil price:

$$
\begin{aligned}
& \triangle \text { REER }_{t}=\mathbf{I}_{t}\left(\gamma+\lambda_{1} \text { MEER }_{t-1}+\sum_{k=1}^{5} \lambda_{2} \Delta \text { REER }_{t-k}+\sum_{k=0}^{5} \lambda_{3} \Delta C O M M_{t-k}\right)+ \\
& \left(1-\mathbf{I}_{t}\right)\left(\gamma^{\prime}+\lambda_{1}^{\prime} M_{E E R_{t-1}}+\sum_{k=1}^{5} \lambda_{2}^{\prime} \Delta R E E R_{t-k}+\sum_{k=0}^{5} \lambda_{3}^{\prime} \Delta C O M M_{t-k}\right)+\varepsilon_{t}
\end{aligned}
$$

where the Boolean indicator I will be equivalent to

$$
\begin{gathered}
\boldsymbol{I} t=1 \text { if } x_{t-d}>\tau \\
\boldsymbol{I} t=0 \text { otherwise }
\end{gathered}
$$

Where $\tau=\Delta O I L_{t-d}$ represents the threshold value. In order to identify $\tau$, we performed an F-test to determine whether the coefficients in the two branches of the right hand side of Equation (3) are equal. The consistent estimate of is then retrieved by running a grid search across all the potential values of the threshold. Being $\tau$ an unidentified nuisance parameter under the null of linearity, and being the model evaluated for every $k$ up to order 5, we follow Hansen (1997) and bootstrap the p-values of the test.

\section{Unit root tests, Co-integration, and DOLS estimates}

This Section reviews the results on the unit root tests, ${ }^{12}$ the co-integration tests and reports a DOLS estimate of the co-integrating relationships. As we analyzed the Perron tests jointly with the Lagrangian Multiplier tests, we could verify that all the first-order differences resulted to be stationary, and thus proceeded to evaluate the variables in their levels. The Lagrangian Multiplier tests were generally less conservative than the residual based tests for the REER, as they could reject less the null hypothesis of unit root, while the tests for the commodity prices were,

${ }^{12}$ Our analysis focuses on the case of a single break deterministic break. Results for the unit root tests are available on request. 
especially in the one break specification, quite close save some minor differences. Being evidence slightly conflicting and given the slight advantage of the LM tests for trending variables as they nest possible deterministic breaks in the alternative hypothesis reducing the ambiguity of the results, we prioritized results from the Lee-Strazicich tests in their one break, trending specification and proceeded to couple exchange rates and commodities. Co-integration tests for the selected couples are reported in Table 3. The latter table reports the results for the Gregory and Hansen (1996a) residual-based co-integration test with one endogenous structural break and, by series inspection and consistently with the unit roots results, assuming an unbroken deterministic trend. Aside from testing for the commodity country pairs with the $\mathrm{C}=\mathrm{T}$ test and the model A test, we also adopted the standard Engle and Granger (1987) methodology. The Carrion-i Silvestre and Sanso (2006) test would generally confirm the results of the Gregory and Hansen (1996a) $C=T$ specification and suggest four more co-integrated couples. Out of the twenty-five original pairs, eight showed evidence of co-integration.

Table 3

\section{COINTEGRATION TESTS}

\begin{tabular}{|l|l|c|c|c|c|c|}
\hline REER_\{t $\}$ & COMM_\{t $\}$ & SC_ $\{\mathbf{a}\}(\boldsymbol{\lambda})$ & Break & $\begin{array}{c}\text { ADF^ }\{*\} \\
\mathbf{C} / \mathbf{T}\end{array}$ & Break & ADF \\
\hline \multicolumn{1}{|c|}{$(\mathbf{I})$} & \multicolumn{1}{c|}{$(\mathbf{I I})$} & $(\mathbf{I I I})$ & $(\mathbf{I V})$ & $(\mathbf{V})$ & $(\mathbf{V I})$ & $(\mathbf{V I I})$ \\
\hline BDI & COFFEE & 0.09 & $1980: 08$ & -3.36 & $2010: 03$ & -2.72 \\
\hline CHL & COPPER & 0.10 & $1996: 01$ & -4.05 & $1985: 05$ & $-1,91$ \\
\hline CIV & COCOA & 0.06 & $1986: 12$ & -4.33 & $1993: 12$ & $-2,94$ \\
\hline GHA & COCOA & 0.04 & $1983: 11$ & $* * *-5.87$ & $1985: 05$ & $-3,49$ \\
\hline PRY & SOYA & 0.07 & $1988: 01$ & -3.38 & $1985: 06$ & -2.70 \\
\hline ZMB & COPPER & 0.09 & $1988: 07$ & $* * *-5.83$ & $2005: 09$ & $* *-3.82$ \\
\hline UGA & COFFEE & $* * 0.12$ & $1981: 06$ & $* * *-7.15$ & $1991: 01$ & $* *-4.96$ \\
\hline GHA & GOLD & 0.08 & $1983: 12$ & $* * *-5.92$ & $1985: 05$ & -2.11 \\
\hline Selection of countries from Cashin et a. (2004) & & & \\
\hline AUS & COAL & 0.06 & $2004: 03$ & $* * *-4.98$ & $2010: 04$ & $* *-4.30$ \\
\hline PHL & COCONUT & 0.05 & $2002: 06$ & -4.05 & $1999: 01$ & -3.46 \\
\hline PNG & COPPER & $* * * 0.16$ & $2011: 10$ & $* * *-5.36$ & $2009: 11$ & -1.48 \\
\hline
\end{tabular}

Real Effective Exchange Rates and Commodity prices. Column (3), Carrion and Sanso (2006) test; column (5), mimimum ADF test from Gregory and Hansen (1996); column (7), ADF test statistic. ***, significant at 1 per cent; **, significant at 5 per cent. 
Table 4

DOLS ESTIMATES I

\begin{tabular}{|l|c|c|c|c|c|c|}
\hline REER $_{\mathbf{t}}$ & COMM $_{\mathbf{t}}$ & $\boldsymbol{\beta}$ & $\boldsymbol{\alpha}_{\mathbf{1}}$ & $\mathbf{t}$ & $\mathbf{D U}_{\mathbf{t}}$ & $\mathbf{a d j .} \mathbf{R}^{\mathbf{2}}$ \\
\hline \multicolumn{1}{|c|}{$(\mathbf{I})$} & $(\mathbf{I I})$ & $(\mathbf{I I I})$ & $(\mathbf{I V})$ & $(\mathbf{V})$ & $(\mathbf{V I})$ & $(\mathbf{V I I})$ \\
\hline BDI & COFFEE & 0.40 & 2.95 & -0.01 & 0.31 & 0.82 \\
\hline & & $(0.04)$ & $(0.31)$ & $(0.00)$ & $(0.26)$ & \\
\hline CHL & COPPER & 0.31 & 3.55 & -0.01 & 0.34 & 0.36 \\
\hline & & $(0.06)$ & $(0.24)$ & $(0.00)$ & $(0.00)$ & \\
\hline CIV & COCOA & 0.22 & 3.64 & -0.01 & 0.27 & 0.28 \\
\hline & & $(0.06)$ & $(0.34)$ & $(0.00)$ & $(0.07)$ & \\
\hline GHA & COCOA & 0.66 & 4.23 & -0.01 & -1.79 & 0.94 \\
\hline & & $(0.09)$ & $(0.47)$ & $(0.00)$ & $(0.11)$ & \\
\hline PRY & SOYA & 0.50 & 2.50 & -0.01 & -0.32 & 0.78 \\
\hline & & $(0.06)$ & $(0.32)$ & $(0.00)$ & $(0.05)$ & \\
\hline
\end{tabular}

Columns (1) and (2), Real Effective Exchange Rates and Commodity prices. Column (3), DOLS estimates of the long run elasticity; columns (4), (5) and (6), deterministic estimates (intercept, trend, level break); column (7), adjusted $\mathrm{R}^{2}$.*** implies significance at 1 percent; ** implies significance at 5 percent. Lags and Leads specification based on AIC, starting from a maximum of seventeen. Deterministics include a trend and a break in the levels of the co-integrating relationships.

Table 5

\section{DOLS ESTIMATES II}

\begin{tabular}{|c|c|c|c|c|c|c|}
\hline REER $_{t}$ & $\mathrm{COMM}_{\mathrm{t}}$ & $\boldsymbol{\beta}$ & $\alpha_{1}$ & $\mathbf{t}$ & $\mathrm{DU}_{\mathrm{t}}$ & adj. $R^{2}$ \\
\hline (I) & (II) & (III) & (IV) & (V) & (VI) & (VII) \\
\hline \multirow[t]{2}{*}{ ZMB } & COPPER & 0.25 & 3.16 & 0.01 & 0.04 & 0.82 \\
\hline & & $(0.04)$ & $(0.21)$ & $(0.00)$ & $(0.11)$ & \\
\hline \multirow[t]{2}{*}{ UGA } & COFFEE & 0.66 & 2.92 & -0.01 & -0.22 & 0.83 \\
\hline & & $(0.09)$ & $(0.72)$ & $(0.00)$ & $(0.59)$ & \\
\hline \multirow[t]{2}{*}{ GHA } & GOLD & 0.31 & 5.87 & -0.01 & -1.67 & 0.89 \\
\hline & & $(0.11)$ & $(0.54)$ & $(0.00)$ & $(0.15)$ & \\
\hline \multicolumn{7}{|c|}{ Selection of countries from Cashin et a. (2004) } \\
\hline \multirow[t]{2}{*}{ AUS } & COAL & 0.39 & 2.83 & -0.01 & 0.02 & 0.75 \\
\hline & & $(0.04)$ & $(0.04)$ & $(0.00)$ & $(0.04)$ & \\
\hline \multirow[t]{2}{*}{ PHL } & COCONUT & 0.42 & 2.52 & 0.00 & -0.18 & 0.65 \\
\hline & & $(0.04)$ & $(0.18)$ & $(0.01)$ & $(0.04)$ & \\
\hline \multirow[t]{2}{*}{ PNG } & COPPER & 0.29 & 3.73 & -0.01 & 0.35 & 0.83 \\
\hline & & $(0.03)$ & $(0.12)$ & $(0.00)$ & $(0.04)$ & \\
\hline
\end{tabular}

Columns (1) and (2), Real Effective Exchange Rates and Commodity prices. Column (3), DOLS estimates of the long run elasticity; columns (4), (5) and (6), deterministic estimates (intercept, trend, level break); column (7), adjusted $\mathrm{R}^{2}$. *** implies significance at 1 percent; ** implies significance at 5 percent. Lags and Leads specification based on AIC, starting from a maximum of seventeen. Deterministics include a trend and a break in the levels of the co-integrating relationships. 
N. RUBINO: Oil volatility pass through and real exchange misalignment in leading commodity exporting countries EKONOMSKI PREGLED, 71 (6) 579-606 (2020)

\subsection{DOLS Estimates}

As a final step for this section, we report the DOLS estimates of the cointegrating relationships in Table 4 and Table 5. A useful way to comment them is to compare them to the most recent results of Bodart, Candelon, and Carpantier (2015), who estimate similar co-integrating vectors. As we account for our real commodity prices as single prices terms of trade, we would expect them to be positively correlated to the REER. This is generally confirmed for every co-integrating vector. The results, with the exception of a set of three countries which we took from Cashin, Cespedes, and Sahay (2004) to act as a benchmark and that were excluded by Bodart, Candelon, and Carpantier (2015) to respect their export weight threshold, appear comparable to the FM-OLS (the fully modified ordinary least square estimator by Phillips and Hansen (1990)) estimations of the former authors. ${ }^{13}$ Deterministic components also appear fairly significative: the presence of a trend is generally accepted in every specification, and is constantly negative as it rejects the secular decline of commodity prices, suggesting supporting evidence of the Prebisch-Singer hypothesis. ${ }^{14}$ Most notably, the inclusion of a structural break in the relationship is overall accepted by every specification. As we were con dent enough to take into consideration the results, the Misalignment was calculated, in the case of Australia and the price of coal, as:

$M E E R_{A U S, t}=R E E R_{A U S, t}-\left(\hat{\alpha}_{1, A U S}+\hat{\beta}_{A U S} * \operatorname{coal}_{t}-\hat{\alpha}_{2, A U S} * t+\hat{\alpha}_{3, A U S} * D U_{t}\right)$

and so forth for every single country-commodity pair which was found to be cointegrated. In the next section, we take this derived measure of misalignment and, after conducting the tests for linearity based on the cross product of the terms in the linear specification for $F=0$, we analyze the oil price pass-through on the exchange rate.

${ }^{13}$ For an overview of the varied attempts at capturing these elasticities, see the literature in Table 14 in the appendix of this article. We choose to estimate through DOLS as the estimator presents a similar asymptotic distribution but has smaller size distortions than the FM-OLS.

14 The hypothesis has found some recent support in Harvey, Kellard, Madsen, and Wohar (2010), where the series for twenty-five commodities extended to up to four-hundred year showed a significant negative trend. 


\section{Linearity tests and Estimation of the transition regression model}

Estimating a transition model normally requires a grid-search across all feasible values for the selected threshold in a trimmed interval of the sample. 1.2 Thanks to the previous steps we assume to have already accounted for changes in the equilibrium relationship depending on time, which are now already present in the misalignment measure. We hope to uncover a nonsymmetric and nonlinear behavior in the Exchange rates conditional on a threshold value $\tau$, as defined in section 1.2.

In our estimation strategy, equation 3 is estimated across all the possible values of $\Delta O I L_{t-d}=\tau \forall d \in(0 ; k)$, where $k=\left[4(T / 100)^{2 / 9}\right]$, and the lagged value of the oil price with the delay value which implies the higher F-statistic and the smaller squared error is chosen.

Table 6

\section{LINEARITY TESTS}

\begin{tabular}{|l|l|c|c|c|c|c|}
\hline REER $_{\mathbf{t}}$ & COMM $_{\mathbf{t}}$ & $\mathbf{d}$ & $\boldsymbol{\tau}_{\mathbf{t}-\mathbf{d}}$ & $\mathbf{F}$-stat & p-value(b) & RSS \\
\hline \multicolumn{1}{|c|}{$(\mathbf{I})$} & $(\mathbf{I I})$ & $(\mathbf{I I I})$ & $(\mathbf{I V})$ & $(\mathbf{V})$ & $(\mathbf{V I})$ & $(\mathbf{V I I})$ \\
\hline BDI & COFFEE & 4 & 0.04 & 2.42 & 0.09 & 390.11 \\
\hline CHL & COPPER & 1 & 0.05 & 5.96 & 0.00 & 429.76 \\
\hline CIV & COCOA & 4 & -0.06 & 11.05 & 0.00 & 415.34 \\
\hline GHA & COCOA & 1 & -0.02 & 42.16 & 0.00 & 415.34 \\
\hline PRY & SOYA & 4 & 0.01 & 2.51 & 0.07 & 406.21 \\
\hline ZMB & COPPER & 2 & 0.01 & 3.06 & 0.06 & 318.01 \\
\hline UGA & COFFEE & 1 & -0.03 & 18.34 & 0.00 & 428.98 \\
\hline GHA & GOLD & 5 & 0.01 & 19.42 & 0.00 & 365.46 \\
\hline Selection of fountries from Cashin et al. $(2004)$ & & & \\
\hline PHL & COCO & 4 & -0.01 & 4.26 & 0 & 335.60 \\
\hline AUS & COAL & 3 & -0.06 & 3.70 & 0.00 & 385.82 \\
\hline PNG & COPPER & 3 & -0.05 & 3.32 & 0.01 & 401.55 \\
\hline
\end{tabular}

Columns (1) and (2), Real Effective Exchange Rates and Commodity prices. Column (3), threshold delay. Column (4), selected threshold value. Columns (5) and (6), Hansen F-test and bootstrapped p-value (5000 iterations). 
However, the idea that the REER begins its transition to its fundamental attractor value immediately after a variation in prices in the same period or with more than a few months of delay might appear a not sensible choice. That is why our selection across all the feasible models is limited to between one and four delays. ${ }^{15}$ Before presenting the results for the estimates of the two regime specifications, we present the bootstrapped version of the Hansen (1997) test to detect hint of nonlinearity and look for the most suitable threshold. ${ }^{16}$ The tests are shown in Table 6 and the goodness of fit of the nonlinear models with respect to the linear specifications is reported in Table 7.

All the tests appear to point, conditional on the choice of the best delay across the specified lag truncations, at rejecting the null hypothesis of no threshold behavior. The estimates furthermore, would appear quite reasonable as they would point at an average threshold value fairly close to zero, with delays ranging from one to five. ${ }^{17}$

15 This choice was partially justified by Michael, Nobay, and Peel (1997), and it depends on prior assumptions on the delay suffered by the reactions of the economic agents. The former authors would consider up to three delays, while in Bunzel and Enders (2010), who similarly to us choose the delay based on the best fitting regression, the range is limited to just two periods.

16 That is, just to recall, that the null hypothesis would be $\alpha_{i}=\beta_{i}$.

17 To be more specific, we set $c$ to be equal to the variation of the oil prices series and executed a grid-search through all feasible values of such threshold to get a data dependent estimate for $\gamma$. This procedure was repeated for any delay from one to 5, and the best nonlinear model was chosen based on the linearity test, its Aikake information criteria value, and the absence of non-spherical disturbances in the post-estimation checks. 
Table 7

\section{MODELS' GOODNESS OF FIT}

\begin{tabular}{|l|l|c|c|c|c|}
\hline \multicolumn{1}{|c|}{ REER $_{\mathbf{t}}$} & \multicolumn{1}{c|}{ COMM $_{\mathbf{t}}$} & Lags & OBS & Threshold AIC & Linear AIC \\
\hline BD & \multicolumn{1}{c|}{$(\mathbf{I I})$} & $(\mathbf{I I I})$ & $(\mathbf{I V})$ & $(\mathbf{V})$ & $(\mathbf{V I})$ \\
\hline CHL & COFFE & 4 & 427 & -1739.78 & -1735.82 \\
\hline CIV & COPPER & 1 & 430 & -2010.33 & -1993.12 \\
\hline GHA & COCOA & 4 & 427 & -1753.42 & -1663.33 \\
\hline PRY & COCOA & 1 & 431 & -1072.87 & -907.97 \\
\hline ZMB & SOYA & 4 & 427 & -1565.55 & -1559.85 \\
\hline UGA & COPPER & 2 & 333 & -1042.30 & -1039.11 \\
\hline GHA & COFFEE & 1 & 430 & -583.89 & -590.86 \\
\hline Selection of countries from Cashin et a. $(2004)$ & 426 & -1111.56 & -929.16 \\
\hline PHL & GOLD & 5 & 427 & -1974.96 & -1950.18 \\
\hline AUS & COCO & 4 & 428 & -2094.218 & -2079.15 \\
\hline PNG & COAL & 3 & 428 & -2028.07 & -2016.18 \\
\hline
\end{tabular}

Columns (1) and (2), Real Effective Exchange Rates and Commodity prices. Columns (5) and (6), A comparison of the minimum Aikake information criteria for the selected threshold models with respect to the linear specification.

\subsection{Transition regression model results}

Estimates of the models for the sample of selected countries are reported in Table 8 and 5. The threshold parameter allowed us to estimate two regimes: one where oil price variations are higher than the threshold, and a regime of low volatility below the same threshold. The dimension and importance of the speed of mean reversion greatly varies not just across countries but also across price regimes. Some key findings can be highlighted, conditional on the exogeneity of oil prices: first of all, in the negative volatility regime, the real exchange rate has a faster tendency to return to its fundamental value after a shock in the majority of the country we considered. This could be explained, as we stated before, by the role of transaction costs, captured by transportation costs and proxied by oil prices. On the other hand, the value of the misalignment coefficient in the positive volatility regime is relatively higher and at times significative, as we assume that transportation costs only represent a fraction of total trade frictions. Given that the 
commodity prices considered are international prices, an equivalent specification of a transition regression model where $\triangle C O M M$ represents the dependent variable should not show any adjustment and any exogenous shock to the system should causally affect commodity prices before it affects exchange rates. This is generally confirmed in six out of the eight countries which made it past the previous unit root and co-integration analyses, and it is visible in column V II of Table 8 and 9, were the null of weak exogeneity and causal priority based on the Engle (1984) test was generally not rejected. As a last exercise, we compare the implied half-lives of the deviations of the REER across the regimes and employing a naive PPP-consistent first order autoregressive process. The results are visible in Table 10.

\section{Table 8}

\section{ESTIMATES, EXOGENEITY AND CAUSALITY}

\begin{tabular}{|l|l|c|c|c|c|c|c|}
\hline REER $_{\mathbf{t}}$ & COMM $_{\mathbf{t}}$ & $\begin{array}{c}\boldsymbol{\lambda}_{\mathbf{1}}^{\prime} \\
\text { Positive }\end{array}$ & $\begin{array}{c}\boldsymbol{\lambda}_{\mathbf{1}} \\
\text { Negative }\end{array}$ & Linear & Lags & $\begin{array}{c}\text { Engle } \\
(\mathbf{1 9 8 4})\end{array}$ & Linearity \\
\hline \multicolumn{1}{|c|}{$(\mathbf{I})$} & $(\mathbf{I I})$ & $(\mathbf{I I I})$ & $(\mathbf{I V})$ & $(\mathbf{V})$ & $(\mathbf{V I})$ & $(\mathbf{V I I})$ & $(\mathbf{V I I I})$ \\
\hline BDI & COFFEE & -0.02 & -0.05 & -0.05 & 4 & 6.89 & 0.3006 \\
\hline & & $(-0.88)$ & $(-3.44)$ & $(-3.45)$ & & & \\
\hline CHL & COPPER & -0.04 & -0.01 & -.020 & 1 & $* * * 10.01$ & 0.2637 \\
\hline & & $(-1.96)$ & $(-1.50)$ & $(-2.11)$ & & & \\
\hline CIV & COCOA & -0.02 & -0.19 & -0.05 & 4 & 1.83 & 0.0000 \\
\hline & & $(-1.84)$ & $(-5.54)$ & $(-2.08)$ & & & \\
\hline GHA & COCOA & 0.02 & -0.08 & -0.02 & 1 & 2.91 & 0.0000 \\
\hline & & $(3.15)$ & $(-1.62)$ & $(-2.50)$ & & & \\
\hline PRY & SOYA & -0.06 & -0.08 & -0.07 & 4 & $* * * 14.33$ & 0.7482 \\
\hline & & $(-2.05)$ & $(-3.28)$ & $(-3.89)$ & & & \\
\hline
\end{tabular}

Columns (1) and (2), Real Effective Exchange Rates and Commodity prices. Columns (3), (4), (5), error correction term coefficients; column (6), number of lags based on Newey West lags, column (7) and (8), weak exogeneity test and linear restriction tests. Null hypothesis of Engle's test: $H_{0}=\sigma_{12}=\operatorname{corr}\left(e_{t} e_{t}^{\prime}\right)=0$

As we would expect, the autoregressive estimates would indicate half-lives ranging from three to more than six years. The two-regime estimates, with the only puzzling result of the Ghana-Gold couple, where nonlinearity was not rejected if not after a five periods delay, appear to consistently confirm faster mean reversion in the negative volatility regime when compared to the linear model and the PPP definition. 
Table 9

\section{ESTIMATES, EXOGENEITY AND CAUSALITY}

\begin{tabular}{|c|c|c|c|c|c|c|c|}
\hline REER $_{t}$ & $\mathrm{COMM}_{\mathrm{t}}$ & $\begin{array}{c}\lambda_{1}^{\prime} \\
\text { Positive }\end{array}$ & $\begin{array}{c}\lambda_{1} \\
\text { Negative }\end{array}$ & Linear & Lags & $\begin{array}{l}\text { Engle } \\
(1984)\end{array}$ & Linearity \\
\hline (I) & (II) & (III) & (IV) & $(\mathbf{V})$ & $(\mathrm{VI})$ & (VII) & (VIII) \\
\hline \multirow[t]{2}{*}{$\mathrm{ZMB}$} & COPPER & -0.11 & -0.25 & -0.14 & 2 & 5.20 & 0.0135 \\
\hline & & $(-3.08)$ & $(-3.01)$ & $(-3.95)$ & & & \\
\hline \multirow[t]{2}{*}{ UGA } & COFFEE & -0.07 & -0.07 & -0.07 & 1 & 0.32 & 0.9748 \\
\hline & & $(-1.06)$ & $(-1.36)$ & $(-1.32)$ & & & \\
\hline \multirow[t]{2}{*}{ GHA } & GOLD & -0.18 & 0.01 & -0.07 & 5 & 2.00 & 0.0000 \\
\hline & & $(-9.12)$ & $(0.13)$ & $(-5.64)$ & & & \\
\hline \multicolumn{8}{|c|}{ Selection of countries from Cashin et al. (2004) } \\
\hline \multirow[t]{2}{*}{ AUS } & COAL & -0.04 & -0.05 & -0.03 & 3 & $* * * 34,08$ & 0.8286 \\
\hline & & $(-3.02)$ & $(-1.45)$ & $(-2.34)$ & & & \\
\hline \multirow[t]{2}{*}{ PHL } & COCONUT & -0.01 & -0.09 & -0.04 & 4 & $* * * 20.73$ & 0.0002 \\
\hline & & $(-0,47)$ & $(-5.34)$ & $(-2.54)$ & & & \\
\hline \multirow[t]{2}{*}{ PNG } & COPPER & -0.03 & -0.08 & -0.04 & 3 & $* * * 10.03$ & 0.2055 \\
\hline & & $(-2.54)$ & $(2.30)$ & $(-3.08)$ & & \multicolumn{2}{|c|}{ [3.06 in Neg.] } \\
\hline
\end{tabular}

Columns (3), (4), (5), speed of adjustment lambda coefficients; column (7) and (8), Exogeneity and F-linear tests. 
N. RUBINO: Oil volatility pass through and real exchange misalignment in leading commodity exporting countries EKONOMSKI PREGLED, 71 (6) 579-606 (2020)

Table 10

HALF-LIVES ESTIMATES, BEHAVIOURAL AND PPP

\begin{tabular}{|l|l|c|c|c|c|}
\hline \multicolumn{1}{|c|}{ REER $_{\mathbf{t}}$} & COMM $_{\mathbf{t}}$ & $\boldsymbol{\lambda}_{\mathbf{1}}^{\prime}(\mathbf{t})$ Positive & $\boldsymbol{\lambda}_{\mathbf{1}}(\mathbf{t})$ Negative & $\boldsymbol{\lambda}(\mathbf{t})$ Linear & $\boldsymbol{\lambda}(\mathbf{t}) \mathbf{A R}(\mathbf{1})$ \\
\hline \multicolumn{1}{|c|}{$(\mathbf{I})$} & \multicolumn{1}{c}{$(\mathbf{I I})$} & $(\mathbf{I I I})$ & $(\mathbf{I V})$ & $(\mathbf{V})$ & $(\mathbf{V I})$ \\
\hline BDI & COFFE & 30.35 & 12.53 & 14.86 & 112.84 \\
\hline CHL & COPPER & 17.23 & 47.71 & 14.86 & 58.96 \\
\hline CIV & COCOA & 27.90 & 3.37 & 15.03 & 19.58 \\
\hline GHA & COCOA & 33.93 & 8.57 & 37.92 & 114.03 \\
\hline PRY & SOYA & 10.73 & 8.92 & 9.37 & 34.83 \\
\hline ZMB & COPPER & 6.18 & 2.38 & 4.73 & 32.98 \\
\hline UGA & COFFEE & 9.51 & 9.90 & 9.46 & 31.35 \\
\hline GHA & GOLD & 3.49 & 380.06 & 8.70 & \\
\hline Selection of countries from Cashin et al. (2004) & & & \\
\hline PHL & COCONUT & 99.60 & 7.15 & 19.45 & 40.49 \\
\hline AUS & COAL & 15.56 & 13.00 & 23.54 & 5.16 \\
\hline PNG & COPPER & 19.48 & 7.81 & 16.89 & 73.14 \\
\hline
\end{tabular}

Real Effective Exchange Rates and Commodity prices. Columns (3), (4), (5), half-life estimates of the error correction parameters, calculated according to $\alpha_{i}=\beta_{i}$. Column (6): PPP naive estimates. Monthly frequency.

\section{Conclusions}

In this paper, we adopted a transition regression model with an exogenous oil price variation threshold for a set of twenty-five commodity exporting countries, focusing on the price of one of their leading exported commodities and attempting to explore the relationship between commodity prices, $R E E R$, and oil price passthrough in a sample covering the 1980-2015 period. After accounting for a possible break in the series and in the long run relationships to test for co-integration between $R E E R$ and oil price, we analyzed the effects of oil price volatility on $R E E R$ misalignment in a regime switching regression model. Our results show evidence of a possible long run relationship between the REER and leading commodity prices in eight out of the twenty-five countries analyzed, which would account for around $30 \%$ of the initial sample. After calculating a misalignment value and fitting it into a threshold model, we concluded that the REER-Commodity price behavioral equilibrium appears to be nonlinear with respect to oil price exogenous 
variations; the goodness of fit of nonlinear specifications generally outperforms that of linear specifications; the equilibrium speed of adjustment differs across the two branches of the relationship and it is significantly higher in the negative volatility regime, with implied half-lives lower than those indicated by the PPP puzzle. Our analysis excludes those countries whose leading commodity prices was identified as crude petroleum by Bodart, Candelon, and Carpantier (2015). Further developments of the analysis might include those countries, coupled with the second, most relevant commodity price according to its export weight. Furthermore, forecasting exercises might be conducted in the two regimes, and the resulting forecasts compared to the canonical random walk representation. The analysis of REER misalignments in a price pass-through framework holds important policy implications: it introduces an important cut off point in the analysis of the REER, influencing stabilization policies related to the control of real and nominal exchange rates, anchoring the desired target of this variable to the behavior of commodity prices, especially energetic ones. Further research on the interaction between prices and exchange rates in a nonlinear fashion is thus advisable.

\section{References}

1. Baffes, J. (2007): Oil spills on other commodities, Resources Policy, 32(3), 126-134.

2. Baum, C. F., J. T. Barkoulas, and M. Caglayan (2001): Nonlinear adjustment to purchasing power parity in the post-Bretton Woods era, Journal of International Money and Finance, 20(3), 379-399.

3. Bodart, V., B. Candelon, and J. F. Carpantier (2015): Real exchange rates, commodity prices and structural factors in developing countries, Journal of International Money and Finance, 51(C), 264-284.

4. Bodart, V., B. Candelon, and J. F. Carpentier (2012): Real Exchange Rates in Commodity Producing Countries: A Reapprisal, Journey of International Money and Finance, 31, 1482-1502.

5. Bunzel, H., and W. Enders (2010): The Taylor Rule and "Opportunistic" monetary policy, Journal of Money, Credit and Banking, 42(5).

6. Carrion-i Silvestre, J. L., and A. Sanso (2006): Testing the null of cointegration with structural break, Oxford Bulletin Of Economics and Statistics, 68, 623-646.

7. Cashin, P., L. F. Cespedes, and R. Sahay (2004): Commodity Currencies and the Real Exchange Rate, Journal of Development Economics, 75, 239-268. 
N. RUBINO: Oil volatility pass through and real exchange misalignment in leading commodity exporting countries EKONOMSKI PREGLED, 71 (6) 579-606 (2020)

8. Cavalcanti, T. V. d. V., K. Mohaddes, and M. Raissi (2011): Growth, development and natural resources: New evidence using a heterogeneous panel analysis, The Quarterly Review of Economics and Finance, 51, 305-318.

9. Cavalcanti, T. V. d. V., K. Mohaddes, and M. Raissi (2014): Commodity Price Volatility and the Sources of Growth, Journal of Applied Econometrics, DOI: $10.1002 /$ jae.2407.

10. Chaudhuri, K. (2001): Long-run prices of primary commodities and oil prices, Applied Economics, 33, 531-538.

11. Chen, Y., and K. Rogoff (2003): Commodity currencies, Journal of International economics, 60, 133-166.

12. Coudert, V., C. Couharde, and V. Mignon (2015): On the impact of volatility on the real exchange rate-terms of trade nexus: Revisiting commodity currencies, Journal of International Money and Finance, 58, 110-127.

13. Cuddington, J. T., and C. M. Urzua (1989): Trends and Cycles in the Net Barter Terms of Trade: A new Approach, The Economic Journal.

14. Deaton, A., and R. Miller (1996): International commodity prices, macroeconomic performance and politics in Sub-Saharan Africa, Journal of African Economies, 5, 99-191.

15. Dickey, D. A., and S. G. Pantula (1987): Determining the Order of Differencing in Autoregressive Processes, Journal of Business \& Economic Statistics, 5(4), 455-461.

16. Engle, R., and C. Granger (1987): Co-integration and Error Correction: Representation, Estimation and Testing, Econometrica, 55(2), 251-276.

17. Engle, R. F. (1984): Wald, likelihood ratio, and Lagrange multiplier tests in econometrics, Handbook of Econometrics, 2, 776-826.

18. Ferraro, D., K. Rogoff, and B. Rossi (2015): Can oil prices forecast exchange rates? An empirical analysis of the relationship between commodity prices and exchange rates, Journal of International Money and Finance, 54, 116-141.

19. Gregory, A. W., and B. E. Hansen (1996a): Residual-based tests for Cointegration in Models with Regime Shifts, Journal of Econometrics, 70, 99-126.

20. Hamilton, J. D. (1996): This is what happened to the oil pricemacroeconomy relationship, Journal of Monetary Economics, 38, 215-220.

21. (2003): What is an oil shock?, Journal of Econometrics, 113, 363-398.

22. Hansen, B. E. (1997): Inference in TAR Models, Studies in Nonlinear Dynamics and Econometrics, 2(1), 1-14.

23. Harvey, D. I., N. M. Kellard, J. B. Madsen, and M. E. Wohar (2010): The Prebisch-Singer hypothesis: four centuries of evidence, The Review of Economics and Statistics, 92(2), 367-377. 
24. Imbs, J., M. O. Ravn, H. Mumtaz, and H. Rey (2003): Nonlinearities and the real exchange rate, Journal of the European Economic Association, 1, 639-649.

25. Kilian, L., and R. J. Vigfusson (2011): Nonlinearities in the oil priceoutput relationship, Macroeconomic Dynamics, 15, 337-363.

26. Lee, J., and M. C. Strazicich (2001): Break Point Estimation and Spurious Rejections with Endogenous Unit Root Tests, Oxford Bullettin Of Economics and Statistics, 63, 535-558.

27. (2003): Minimum Lagrange Multiplier Unit root test with two structural breaks, The Review of Economics and Statistics, 85(4), 1082-1089.

28. (2013): Minimum LM unit root test with one structural break, Economics Bulletin, 33(4), 2483-2492.

29. Ludwig, A. (2013): Testing the null of cointegration with a structural break: optimal kernel and bandwith selection, Economics Bulletin, 33(4), 2828-2893.

30. MacDonald, R. (1998): What determines real exchange rates?: The long and short of it, Journal of International Financial Markets, Institutions and Money, 8(2), 117-153.

31. Michael, P. A., A. R. Nobay, and D. A. Peel (1997): Transaction Costs and Nonlinear Adjustment in Real Exchange Rates: An empirical Investigation, Journal of Political Economy, 105(4), 862-879.

32. Mork, K. A. (1989): Oil and the macroeconomy. When prices go up and down: an extensionof Hamilton s results, Journal of Political Economy, 97, 740-744.

33. Obstfeld, M., and A. M. Taylor (1997): Nonlinear aspects of goods market arbitrage adjustment: Heckscher's commodity points revisited, Journal of the Japanese and International Economies, 11, 441-479.

34. Papell, D. H., and R. Prodan (2006): Additional Evidence of LongRun Purchasing Power Parity with Restricted structural change, Journal of Money, Credit and Banking, 38(5), 1329-1349.

35. Perron, P. (1997): Further evidence on breaking trend functions in macroeconomic variables, Journal of Econometrics, 80(2), 355-385.

36. Perron, P., and T. Vogelsang (1992): Nonstationarity hypothesis and level shifts with an application to purchasing power parity, Journal of Business and Economic Statistics, 10, 301-320.

37. (1998): Additional tests for a Unit Root Allowing for A Break in the trend Function at an Unkwnown point of time, International Economic Review, 39(4), 1073-1100. 
N. RUBINO: Oil volatility pass through and real exchange misalignment in leading commodity exporting countries EKONOMSKI PREGLED, 71 (6) 579-606 (2020)

38. Phillips, P. C. B., and B. E. Hansen (1990): Statistical inference in instrumental variables regressions with I(1) processes, Review of Economic Studies, 57, 99-125.

39. Rogoff, K. (1996): The Purchasing Power Parity Puzzle, Journal of Economic Literature, 34(2), 647-668.

40. Stock, J., and M. Watson (1993): A simple Estimator of Cointegrating Vectors in Higher Order integrated Systems, Econometrica, 61(4), 783-820.

41. Taylor, M. P., D. A. Peel, and L. Sarno (2001): Nonlinear MeanReversion in Real Exchange Rates: Toward a Solution to the Purchasing Power Parity Puzzles, International Economic Review, 42(4), 1015-1042.

\section{Appendix}

This section reports the outcome of the REER-commodity coupling procedures (Table 11), a table containing the commodity price series definitions (Table 12), the descriptive statistics of the variables (Table 13), a plot of the time series (Pictures 1 and 2) and a resume of past literature estimates of the elasticity of the Real Exchange Rate to commodity prices in commodity exporting countries (Table 14). 
Figure 1

REAL EFFECTIVE EXCHANGE RATES, 1980-2015. NORMALIZED REER SERIES (BASE MONTH: JANUARY 1995). FROM LEFT TO RIGHT: BURUNDI, CHILE, IVORY COAST, GHANA, PARAGUAY, ZAMBIAAND UGANDA.

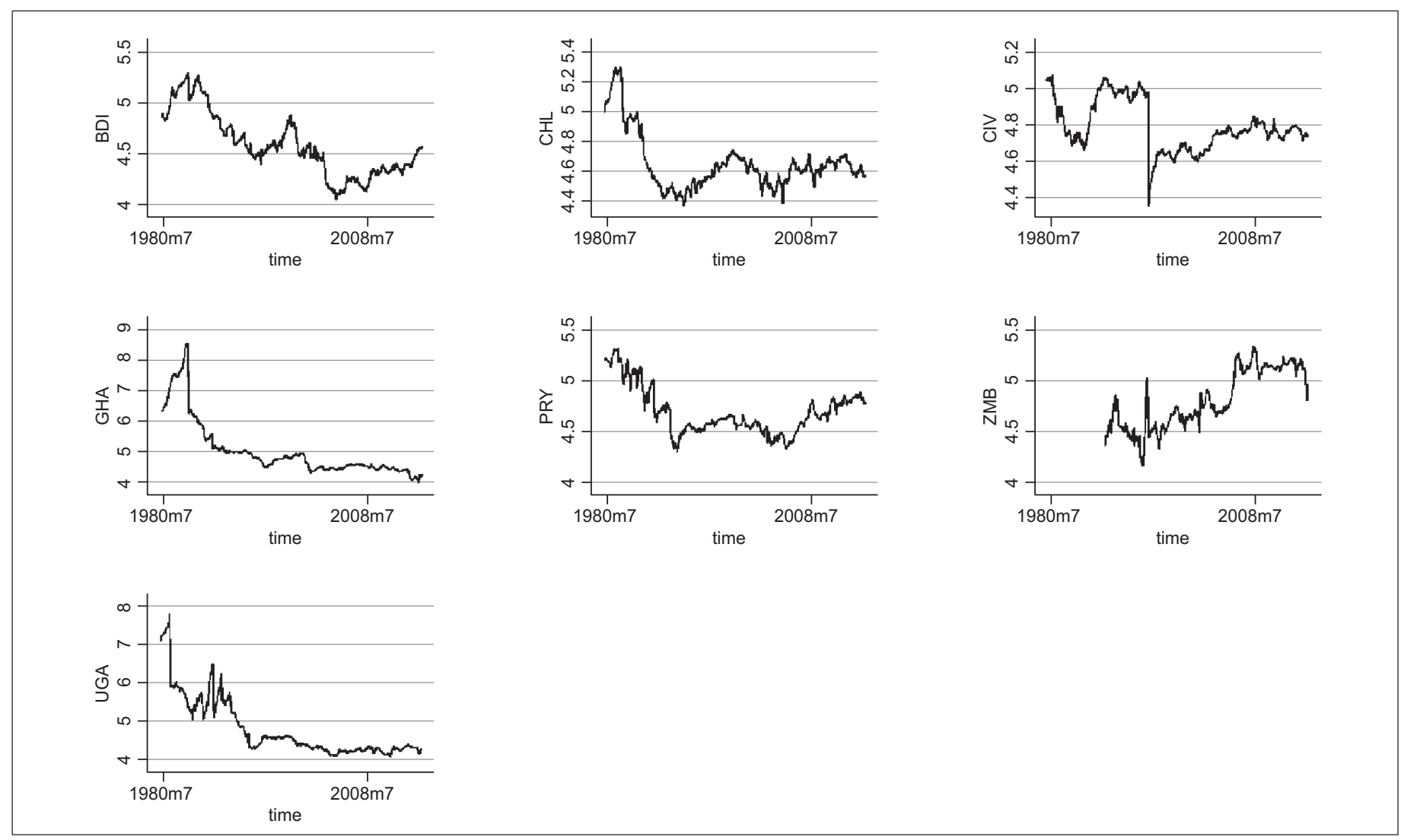


COMMODITIES, 1980-2015. SELECTED INTERNATIONAL PRICE SERIES. NORMALIZED ON JANUARY 1995. FROM LEFT TO RIGHT: COFFEE, COPPER, COCOA, SOYA AND GOLD.

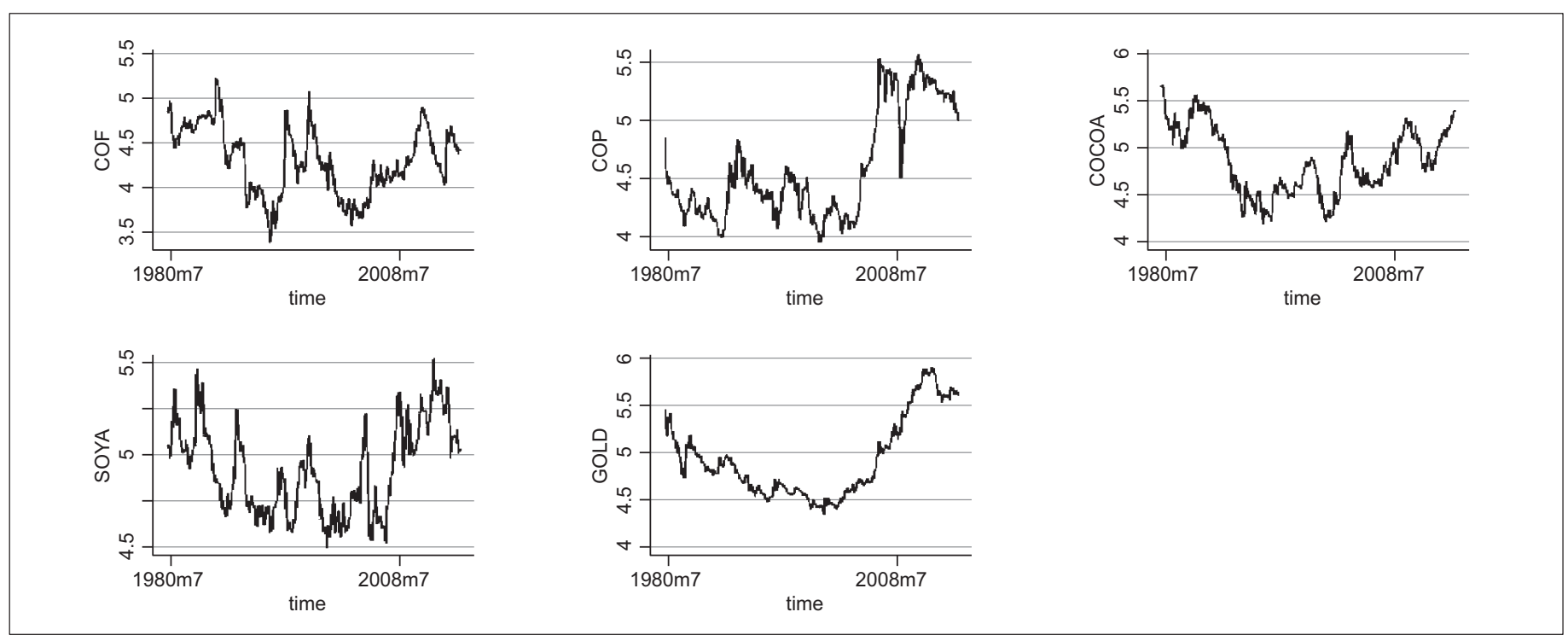


Table 11

\section{VARIABLE COUPLING FOR THE UNIT ROOT AND CO-INTEGRATION TESTS}

\begin{tabular}{|c|c|c|c|c|}
\hline $\mathrm{COMM}_{\mathrm{t}}$ & REER $_{\mathrm{t}}$ & Country Codes & Notes & $\operatorname{Comm}_{\mathrm{t}} \mathrm{I}(\mathbf{0})$ \\
\hline (I) & (II) & (III) & (IV) & $(\mathbf{V})$ \\
\hline \multirow[t]{3}{*}{ Oil } & Nigeria & NGA & excluded & \\
\hline & Yemen & YEM & excluded & \\
\hline & Iran & IRN & excluded & \\
\hline \multirow[t]{3}{*}{ Cotton } & Benin & BEN & not avaiable at IMF & $\mathrm{x}$ \\
\hline & Mali & MLI & not available at IMF & $\mathrm{x}$ \\
\hline & Pakistan & PAK & included & $\mathrm{x}$ \\
\hline \multirow[t]{2}{*}{ Tobacco } & Malawi & MWI & \multicolumn{2}{|l|}{ included (MWI I $(0)$ ) } \\
\hline & Zimbabwe & ZWE & \multicolumn{2}{|l|}{ not avaiable at IMF } \\
\hline \multirow[t]{2}{*}{ Copper } & Zambia & ZMB & included & \\
\hline & Chile & $\mathrm{CHL}$ & included & \\
\hline \multirow[t]{3}{*}{ Gold } & Mali & MLI & \multicolumn{2}{|l|}{ not available IMF } \\
\hline & Burundi & BDI & included & \\
\hline & Ghana & GHA & included & \\
\hline \multirow[t]{3}{*}{ Coffee } & Burundi & BDI & included & \\
\hline & Ethiopia & ETH & \multicolumn{2}{|l|}{ not available at IMF } \\
\hline & Uganda & UGA & included & \\
\hline \multirow[t]{2}{*}{ Uranium } & Niger & NER & \multicolumn{2}{|l|}{ not available IMF } \\
\hline & Benin & BEN & \multicolumn{2}{|l|}{ not available at IMF } \\
\hline \multirow[t]{2}{*}{ Cocoa } & Ivory Coast & CIV & included & \\
\hline & Ghana & GHA & included & \\
\hline Aluminium & Mozambique & MOZ & \multicolumn{2}{|l|}{ not available at IMF } \\
\hline Soya & Paraguay & PRY & included & \\
\hline \multirow[t]{2}{*}{ Fish } & Mauritania & MRT & not available at IMF & $\mathrm{X}$ \\
\hline & Mozambique & MOZ & not present in IMF & $\mathrm{x}$ \\
\hline \multirow[t]{2}{*}{ Bananas } & Dominica & DMA & included & $\mathrm{x}$ \\
\hline & Ecuador & $\mathrm{ECU}$ & included & $\mathrm{X}$ \\
\hline Tea & Kenya & KEN & included & $\mathrm{x}$ \\
\hline Crustaceans & Mozambique & MOZ & \multicolumn{2}{|l|}{ not available IMF } \\
\hline
\end{tabular}

Variable selection. The commodity series were taken from https://stats.ukdataservice.ac.uk/ (COMMODITIES, MARKET PRICES AND UNIT VALUES, IMF), while the real effective exchange rates were sourced from http://data.imf.org/ (REAL EFFECTIVE EXCHANGE RATES BASED ON CONSUMER PRICE INDEXES, IMF). 
N. RUBINO: Oil volatility pass through and real exchange misalignment in leading commodity exporting countries EKONOMSKI PREGLED, 71 (6) 579-606 (2020)

Table 12

\section{COMMODITY PRICES SOURCES AND DEFINITIONS}

\begin{tabular}{|l|c|l|}
\hline COMM $_{\mathbf{t}}$ & Source & Definition \\
\hline Oil & IFS & $\begin{array}{l}\text { WEST TEXAS INTERMEDIATE (Units: US Dollars } \\
\text { per Barrel) }\end{array}$ \\
\hline Cotton & IFS & COTTON: LIVERPOOL (Units: US Cents per Pound) \\
\hline Tobacco & IFS & TOBACCO (Units: US Dollars per Metric Ton) \\
\hline Copper & IFS & COPPER (Units: US Dollars per Metric Ton) \\
\hline Gold & IFS & GOLD (Units: US Dollars per Troy Ounce) \\
\hline Coffee & IFS & COFFEE: OTHER MILDS (Units: US Cents per Pound) \\
\hline Uranium & IFS & URANIUM (Units: Us Dollars per Pound) \\
\hline Cocoa & IFS & COCOA BEANS (Units: US Dollars per Metric Ton) \\
\hline Aluminium & IFS & ALUMINIUM (Units: US Dollars per Metric Ton) \\
\hline Soya & IFS & SOYBEANS: US (Units: US Dollars per Metric Ton) \\
\hline Fish & IFS & FISH: (Units: US Dollars per Kilogram) \\
\hline Bananas & IFS & $\begin{array}{l}\text { BANANAS: LATIN AMERICA (Units: US Dollars per } \\
\text { Metric Ton) }\end{array}$ \\
\hline Tea & IFS & TEA (Units: Us Cents per kilogram) \\
\hline Crustaceans & $*$ & not available at IMF \\
\hline
\end{tabular}

IFS definition of the selected commodities. 
Table 13

\section{DESCRIPTIVE STATISTICS}

\begin{tabular}{|l|c|c|c|c|c|}
\hline \multicolumn{1}{|c|}{ Variables } & mean & sd & min & max & obs \\
\hline OIL & $(\mathbf{I I})$ & $(\mathbf{I I I})$ & $(\mathbf{I V})$ & $(\mathbf{V})$ & $(\mathbf{V I})$ \\
\hline BDI & 5.30 & 0.53 & 4.23 & 6.35 & 6.35 \\
\hline COF & 4.60 & 0.31 & 4.07 & 5.30 & 5.30 \\
\hline CHL & 4.31 & 0.38 & 3.39 & 5.23 & 5.23 \\
\hline COP & 4.66 & 0.19 & 4.37 & 5.31 & 5.31 \\
\hline CIV & 4.60 & 0.46 & 3.96 & 5.58 & 5.58 \\
\hline COCOA & 4.80 & 0.14 & 4.36 & 5.08 & 5.08 \\
\hline GHA & 4.86 & 0.35 & 4.20 & 5.68 & 5.68 \\
\hline PRY & 5.05 & 0.94 & 3.99 & 8.56 & 8.56 \\
\hline SOYA & 4.70 & 0.23 & 4.30 & 5.33 & 5.33 \\
\hline GOLD & 4.92 & 0.24 & 4.50 & 5.52 & 5.52 \\
\hline UGA & 4.82 & 0.43 & 4.35 & 5.91 & 5.91 \\
\hline ZMB & 4.82 & 0.79 & 4.09 & 7.81 & 7.81 \\
\hline DOIL & -0.01 & 0.29 & 4.17 & 5.34 & 5.34 \\
\hline DCOF & -0.01 & 0.08 & -0.39 & 0.40 & 0.37 \\
\hline DCOP & 0.01 & 0.06 & -0.29 & 0.21 & 0.21 \\
\hline DCOCOA & -0.01 & 0.06 & -0.19 & 0.22 & 0.22 \\
\hline DSOYA & $-0,01$ & 0.06 & -0.24 & 0.26 & 0.26 \\
\hline DGOLD & 0.01 & 0.04 & -0.16 & 0.19 & 0.19 \\
\hline DBDI & -0.01 & 0.03 & -0.16 & 0.14 & 0.14 \\
\hline DCHL & -0.01 & 0.02 & -0.15 & 0.13 & 0.13 \\
\hline DCIV & -0.01 & 0.03 & -0.63 & 0.06 & 0.06 \\
\hline DGHA & -0.01 & 0.09 & -1.37 & 0.26 & 0.26 \\
\hline DPRY & -0.01 & 0.04 & -0.31 & 0.12 & 0.12 \\
\hline DUGA & -0.01 & 0.12 & -1.87 & 0.26 & 0.26 \\
\hline DZMB & 0.01 & 0.05 & -0.29 & 0.21 & 0.21 \\
\hline & & & & & \\
\hline
\end{tabular}

Descriptive statistics of the variables in levels and first differences. The threshold variable is highlighted in Bold. Column (II), mean; column (III), standard deviation; columns (IV) and (V) minimum and maximum values of the series; column (VI), total number of observations. 
N. RUBINO: Oil volatility pass through and real exchange misalignment in leading commodity exporting countries EKONOMSKI PREGLED, 71 (6) 579-606 (2020)

Table 14

\section{LONG RUN ELASTICITY, EMPIRICAL STUDIES ON THE REER AS EXPLAINED BY COMMODITY PRICES IN COMMODITY EXPORTING COUNTRIES}

\begin{tabular}{|c|c|c|}
\hline Authors & Sample and Results & Explanatory Variable \\
\hline \multirow[t]{2}{*}{$\begin{array}{l}\text { Amano and Van } \\
\text { Norden (1995) }\end{array}$} & Canada, Monthly 1973-1992 & $\begin{array}{l}\text { Commodity energy Tot; } \\
\text { commodity }\end{array}$ \\
\hline & $\mathrm{LRE}=0.8$ & $\begin{array}{l}\text { non energy TOT; interest rate } \\
\text { differential }\end{array}$ \\
\hline \multirow[t]{2}{*}{$\begin{array}{l}\text { Chen and } \\
\text { Rogoff (2003) }\end{array}$} & $\begin{array}{l}\text { AUS, CAN, NZL, Quarterly, } \\
1984.2001\end{array}$ & Commodity prices \\
\hline & \multicolumn{2}{|l|}{ (2 out of 3 ) $\mathrm{LRE}=0.7$ and 1.0} \\
\hline \multirow[t]{2}{*}{$\begin{array}{l}\text { Mac Donald and } \\
\text { Ricci (2003) }\end{array}$} & RSA, Quarterly, 1970-2001 & $\begin{array}{l}\text { Real commodity price, relative } \\
\text { GDPpc, NFA; }\end{array}$ \\
\hline & $\mathrm{LRE}=0.5$ & $\begin{array}{l}\text { Int. rates, trade openness; fiscal } \\
\text { balance; }\end{array}$ \\
\hline \multirow{2}{*}{$\begin{array}{l}\text { Cashin et al. } \\
(2004)\end{array}$} & 58 Countries, annual 1980-2001 & Commodity ToT. \\
\hline & \multicolumn{2}{|l|}{19 out of 58, median 0.42} \\
\hline \multirow[t]{2}{*}{$\begin{array}{l}\text { Ricci et al. } \\
(2008)\end{array}$} & $\begin{array}{l}\text { Panel, } 48 \text { countries, Annual } \\
1980-2004\end{array}$ & $\begin{array}{l}\text { Commodity ToT; NFA; } \\
\text { productivity diff. }\end{array}$ \\
\hline & Panel cointegration $\mathrm{LRE}=0.5$ & $\begin{array}{l}\text { government cons.; trade restr.; } \\
\text { price restr.; }\end{array}$ \\
\hline \multirow[t]{2}{*}{$\begin{array}{l}\text { Coudert et al. } \\
(2008)\end{array}$} & $\begin{array}{l}\text { Panel, } 52 \text { countries, yearly 1980- } \\
2007\end{array}$ & $\begin{array}{l}\text { logGDP per capita (pod. Proxy), } \\
\text { NFA; }\end{array}$ \\
\hline & $\begin{array}{l}\mathrm{LRE}=0.4010 \text { (controls) } \\
0.6484 \text { (no controls) }\end{array}$ & Commodity ToT. \\
\hline \multirow[t]{3}{*}{$\begin{array}{l}\text { Bodart et al. } \\
(2012)\end{array}$} & $\begin{array}{l}\text { Panel, } 11 \text { countries, monthly } \\
1980-2008\end{array}$ & $\begin{array}{l}\text { Leading Commodity prices; } \\
\text { Structural dummies }\end{array}$ \\
\hline & $\begin{array}{l}\mathrm{LRE}=0.165(\mathrm{BKN}) \text { to } 0.343 \\
(\mathrm{DOLS})\end{array}$ & $\begin{array}{l}\text { (Exchange rates, Financial } \\
\text { Openness, Trade op. }\end{array}$ \\
\hline & & $\begin{array}{l}\text { Export diversification, } \\
\text { Commodity type). }\end{array}$ \\
\hline \multirow[t]{2}{*}{$\begin{array}{l}\text { Bodart et al. } \\
(2015)\end{array}$} & 33 Countries, yearly 1988-2007 & Leading Commodity Prices \\
\hline & \multicolumn{2}{|l|}{17 out of 33, median $=0.21$} \\
\hline
\end{tabular}

Above, a resume of the current literature on the long run elasticity estimates of the relationship between Real exchange rates and commodity prices. 


\title{
PRIJENOS PROMJENA CIJENA NAFTE I NEUSKLAĐENOST REALNOG EFEKTIVNOG TEČAJA U ZEMLJAMA IZVOZNICAMA
}

\author{
Sažetak
}

Prošla istraživanja pokazala su kako realni tečajevi slijede univarijantni nelinearni proces koji aproksimira njihovo ponašanje u terminima transakcijskih troškova. Međutim, malo ili ništa nije rečeno o alternativnim izvorima nelinearnosti u zemljama izvoznicima robe. Ovaj rad istražuje vezu koja nedostaje između ravnoteže realnog deviznog tečaja cijena dobra primjenom mjere volatilnosti cijena nafte kao vanjskog izvora kratkoročnih fluktuacija. Dobivene procjene pokazuju da je odnos cijena realnog deviznog tečaja nelinearan s obzirom na promjenu cijene nafte, te da ocjena primjerenosti nelinearnih specifikacija nadmašuje onu ekvivalentnih linearnih modela. Ravnotežna brzina prilagodbe je različita u dvije grane odnosa: u većini graničnih modela režim negativne volatilnosti predstavlja bržu prilagodbu, a u nekim slučajevima i najznačajniju.

Ključne riječi: tranzicijski regresijski model; realni devizni tečaj; nelinearnosti: cijena nafte; cijena dobara 